\title{
ONLINE V/S TRADITIONAL PEDAGOGY IN PRESENT EDUCATION: A CRITICAL VIEW
}

\author{
Dr. Gaonkar Gopalakrishna M \\ Associate Professor and Head, Dept of Economics, \\ Govt. First Grade College and Centre for PG Studies, Tenkanidiyoor, Udupi -576106
}

\author{
Mr. Manjunatha M \\ Lecturer in Economics, Dept of Economics, Bhandarkars' Arts and Science College Kundapura.
}

Article DOI: $\underline{\text { https://doi.org/10.36713/epra6938 }}$

DOI No: 10.36713/epra6938

\begin{abstract}
"Globalisation, new technologies and demographic developments constitute an enormous challenge; one of the answers to this problem is the access to lifelong learning." - (Jan Figel) Technology has dominated all spheres of life. The education is also one of the fields where we can see the impact of information technology. Over several years the education process has seen drastic changes in imparting knowledge. During the last few years, it has been seen, an almost exponential development and growth of the digitalization, automation and the internet, with little sign of a slowdown. No longer is Internet access restricted to a few selected education establishments it is now available to anyone in their place of work, local libraries, the Internet sites and even in the home. It is the information that has becomes the key to the success in different walks of life. At the time of independence, India inherited an education system with glaring disparities between males and females, between upper and lower classes, between economically advantaged and disadvantaged groups and urban and rural population. Consequently, one of the primary responsibilities of the Government of India after independence was to make education available to all people. This responsibility was sought to be realized through the opening of more and more primary schools, secondary schools and colleges. However, the formal education system alone was found to be unable to meet the demand for education.
\end{abstract}

KEYWORDS: Online, Traditional, Education, Pedagogy, Internet,

\section{INTRODUCTION}

Technology has dominated all spheres of life. The education is also one of the fields where we can see the impact of information technology. Over several years the education process has seen drastic changes in imparting knowledge. During the last few years, it has been seen, an almost exponential development and growth of the digitalization, automation and the internet, with little sign of a slowdown. No longer is Internet access restricted to a few selected education establishments it is now available to anyone in their place of work, local libraries, and the Internet sites and even in the home.
It is the information that has becomes the key to the success in different walks of life. Today, one of the primary responsibility of the Government of India after independence was to make education available to all people. This responsibility was sought to be realized through the opening of more schools and colleges. However, the formal education system alone was found to be unable to meet the demand for education. The report of United Nations Development Programme UNDP (1993) pointed out the fact that only seven percent of the relevant age group is enrolling for higher education in India. 


\section{EPRA International Journal of Research and Development (IJRD)}

Every stage of societal development requires an educational system that can adequately reflect its needs and demands. Currently we are witnessing in education global shifts that reflect changes brought about by computers and communication technology. This shift may be called Electronic Learning, or Elearning. E-learning is a mode of knowledge production and circulation wherein information technologies play a decisive role. The aim of learning is to explore and to add useful knowledge over and above faster copying, searching and distribute.

\section{Concept of Online Education}

The term Online Education means learn through online and it is basically the online delivery of information communication, training and learning. Online Education involves the use of computers and Internet to aid in the learning process. If a computer is a standalone, then we have Computer Learning (CL) that can be used either Computer Based Learning (CBL) or Computer Assisted Learning (CAL). CBL involves the computer taking the place, for the most part, of the teacher, and is popular in distance education. CAL involves a teacher using Online Education to supplement face-to-face teaching. Online Education has a number of other implications such as, Exploration Experience Engagement Ease of use, Empowerment, etc.

\section{Concept of Traditional Education}

The traditional learning comes in basic four forms which are:

1. Classroom sessions: Attending lectures wherein teacher takes lesson topic-by topic or lesson-by- lesson. Generally learning takes place in collaborative atmosphere.

2. The lab sessions: Experiments are carried out in the lab by the teacher and/or by students themselves and study observations/ results of these experiments.

3. Library sessions: Students go to the library and explore books/study notes/magazines on subjects of their interest.

3. Collaborative learning: Students get in touch with co-students and discuss about their queries and get these queries solved by discussion among them or in some Classroom Sessions.

\section{OBJECTIVE}

1. To study the student's propensity for online education.

2. To review the changes in the field of education over a long period of time.

3. To know the need of online education in present scenario.

4. To study the short comings of online education.

\section{METHODOLOGY}

The study is based on primary as well as secondary data sources. The primary data are collected by google form. To collect the data structured questionnaire was circulated among students, respondents selected through random sampling method. Totally 200 students are included in the sample size. Thereafter, tabular analysis is done to analysis Online and Traditional Pedagogy. Simple statistical methods like averages, percentages and graphs are used to analyse. Secondary sources used are published reports, Journals, articles, etc.

\section{RESPONDENTS PROFILE}

Table: 1 Profile of the Respondents.

\begin{tabular}{|c|c|c|c|c|c|}
\hline & Frequency & Percentage & & Frequency & Percentage \\
\hline \multicolumn{3}{|l|}{ Age Groups } & \multicolumn{3}{|c|}{ Male-Female Ratio of Respondents } \\
\hline Below 16 Years & 04 & $02 \%$ & Male & 58 & $29 \%$ \\
\hline 16-20 Years & 148 & $74 \%$ & Female & 142 & $71 \%$ \\
\hline 20-24 Years & 32 & $16 \%$ & Total & 200 & $100 \%$ \\
\hline 24 and Above & 16 & $08 \%$ & \multicolumn{3}{|c|}{ Social Category of Respondents } \\
\hline Total & 200 & $100 \%$ & General & 58 & $29 \%$ \\
\hline \multicolumn{3}{|l|}{ Educational Level } & SC/ST & 06 & $03 \%$ \\
\hline Secondary & 06 & $03 \%$ & $\mathrm{OBC}$ & 136 & $68 \%$ \\
\hline Higher Secondary & 48 & $24 \%$ & Total & 200 & $100 \%$ \\
\hline Graduation & 90 & $45 \%$ & \multicolumn{3}{|c|}{ Current Enrolment Status } \\
\hline Post-Graduation & 48 & $24 \%$ & Full Time & 134 & $67 \%$ \\
\hline Diploma. /Others & 08 & $04 \%$ & Part Time & 66 & $33 \%$ \\
\hline Total & 200 & $100 \%$ & Total & 200 & $100 \%$ \\
\hline
\end{tabular}

Sources:Primary Data 


\section{EPRA International Journal of Research and Development (IJRD)

In this study among the randomly selected students $02 \%$ are from less than 16 years of age, $74 \%$ belonging to 16-20 years age group. In relating to gender representation 29\% representing boys, $71 \%$ students are girls. When we observe their educational level $03 \%$ were having secondary education, $24 \%$ are having higher education as well as post-graduation respectively, $45 \%$ are graduates and $04 \%$ students are from Diploma and other streams. In this study $29 \%$ general category students were participated, $68 \%$ OBC students were participated and $03 \%$ SC and ST students were participated. Here $67 \%$ students were enrolled as full time and remaining 33\% students were enrolled as part time.

\section{ANALYSIS}

\section{Convenience and Participation in Online Class}

The study clearly depicts that traditional classes were more convenient to the students due to the various reason. Especially we found that the students from the rural region face bundle of problems in online class mainly network issues.

Table: 2 Convenience and Participation in Online Class

\begin{tabular}{|l|c|c|c|c|c|}
\hline & Frequency & Percentage & & Frequency & Percentage \\
\hline More Convenient Class & \multicolumn{4}{|c|}{ Participation in Online Class } \\
\hline Online Class & 24 & $12 \%$ & Yes & 188 & $94 \%$ \\
\hline Traditional Class & 176 & $88 \%$ & No & 12 & $06 \%$ \\
\hline Total & 200 & $100 \%$ & Total & 200 & $100 \%$ \\
\hline
\end{tabular}

Table 2 represent $88 \%$ students were prefer traditional class and only $12 \%$ students were gone for online class. From this we can conclude that online class is not a perfect substitute for traditional class just it is a choice but majority students are participating in online class in these days. Here we can observe $94 \%$ students are participating in online class, just $06 \%$ students are not able to participate in online class.

Chart: 1 More Convenience Class

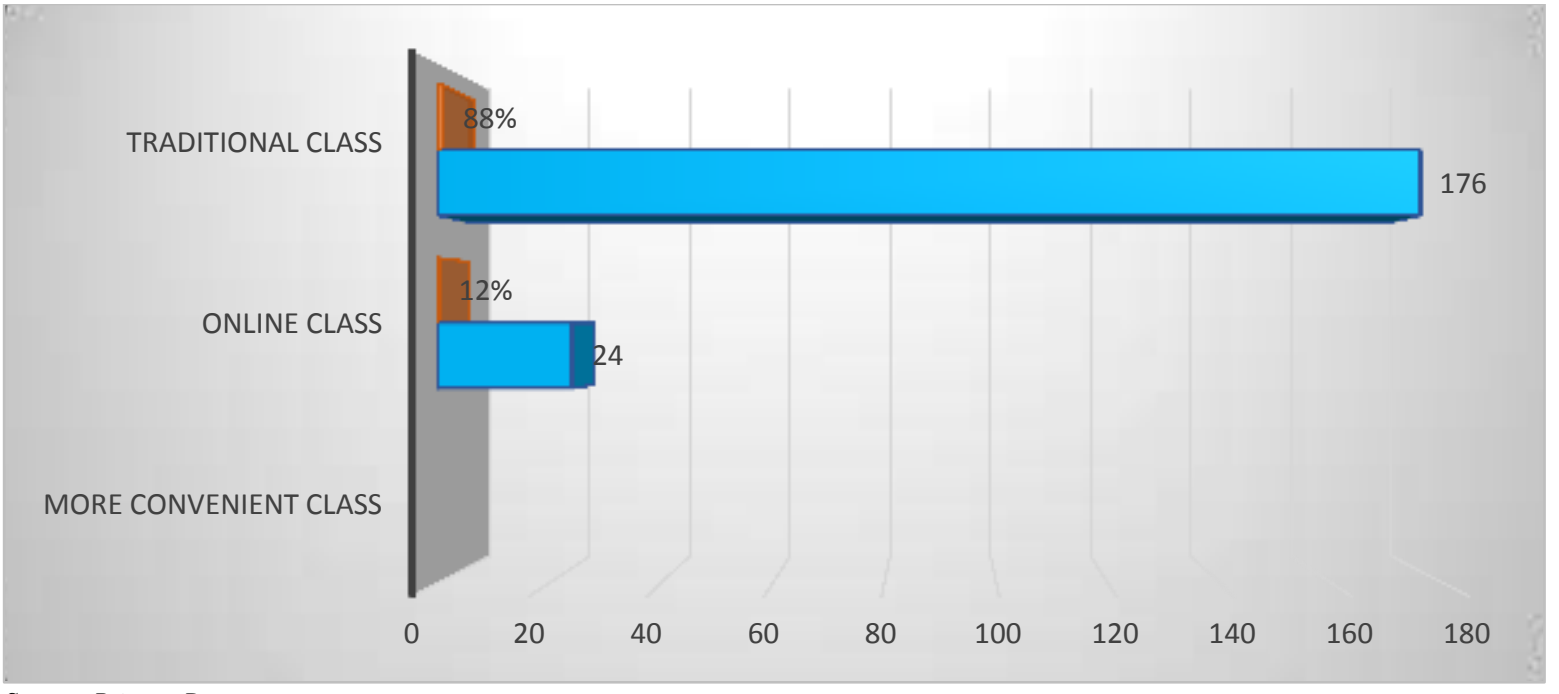

Sources:Primary Data 


\section{EPRA International Journal of Research and Development (IJRD)}

Volume: 6 | Issue: 5 | May 2021

- Peer Reviewed Journal

\section{Difficulties and Differences between Online and Traditional Class}

Table: 3 Difficulties and Differences between Online and Traditional Class

\begin{tabular}{|c|c|c|c|c|c|}
\hline & Frequency & Percentage & & Frequency & Percentage \\
\hline \multicolumn{3}{|c|}{ Online Classes are More Difficult } & \multicolumn{3}{|c|}{ Difference in Online Class } \\
\hline Yes & 148 & $74 \%$ & Much Difference & 82 & $41 \%$ \\
\hline No & 34 & $17 \%$ & Not Much Difference & 42 & $21 \%$ \\
\hline Maybe & 18 & $09 \%$ & Maybe & 76 & $38 \%$ \\
\hline Total & 200 & $100 \%$ & Total & 200 & $100 \%$ \\
\hline \multicolumn{3}{|c|}{ Online Class Type } & \multicolumn{3}{|c|}{ Availability of Instructor } \\
\hline Live Class & 70 & $35 \%$ & Available & 156 & $78 \%$ \\
\hline Recorded Class & 130 & $65 \%$ & Not Available & 44 & $22 \%$ \\
\hline Total & 200 & $100 \%$ & Total & 200 & $100 \%$ \\
\hline
\end{tabular}

In the above table (Table No. 3) we can observe that difficulties in online class and difference between online and traditional class. For $74 \%$ students' online class is more difficult to attend the class as well as to understand the class. $41 \%$ students said that there is much difference between traditional and online class, for $38 \%$ students there maybe the difference between both classes. Majority $65 \%$ students were prefer recorded class instead of live class. $78 \%$ students said that instructors are available for conversation. Here we can conclude that students especially from rural region are facing much difficulties in online class, they always go for traditional class.

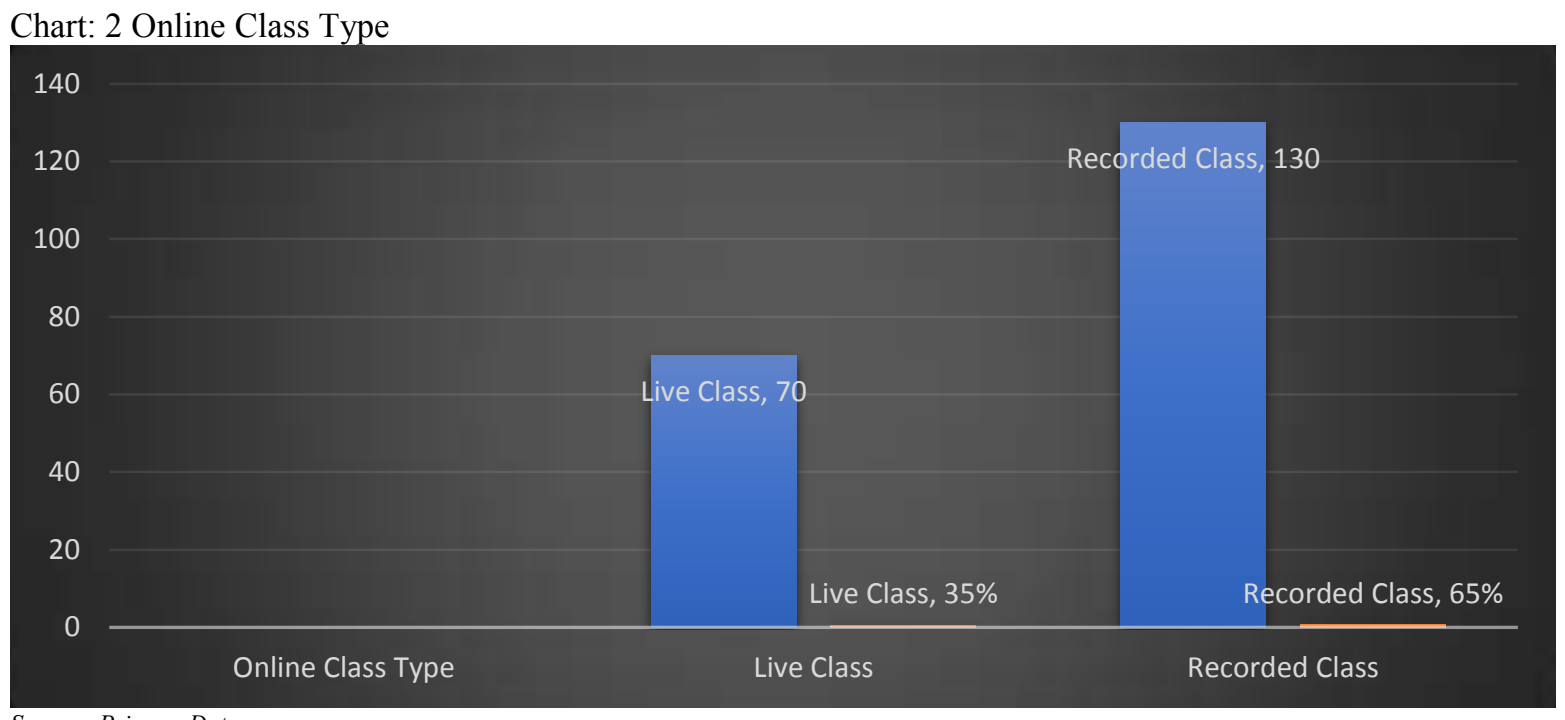

Sources:Primary Data

\section{Device Used for Online Class}

We settled on a definition from Educause "Using portable computing devices (such as iPads, laptops, tablet PCs, PDAs, and smart phones) with wireless networks enables mobility and mobile learning, allowing teaching and learning to extend to spaces beyond the traditional classroom. Within the classroom, mobile learning gives instructors and learners increased flexibility and new opportunities for interaction." Here we can observe that almost all students were settled with smartphones. They use mobile phones regularly even for online class also. 91\% students are using smartphone for online class, a very few students are using other devices like, desktop, laptop, etc. 


\section{EPRA International Journal of Research and Development (IJRD)

Table: 4 Device Used for Online Class

\begin{tabular}{|c|c|c|}
\hline Devices & Frequency & Percentage \\
\hline Desktop PC & 06 & $03 \%$ \\
\hline Laptop PC & 10 & $05 \%$ \\
\hline Smartphones & 182 & $91 \%$ \\
\hline Others & 02 & $01 \%$ \\
\hline Total & 200 & $100 \%$ \\
\hline Sources:Primary Data & \multicolumn{2}{|}{} \\
\hline
\end{tabular}

Chart: 3 Device Used for Online Class

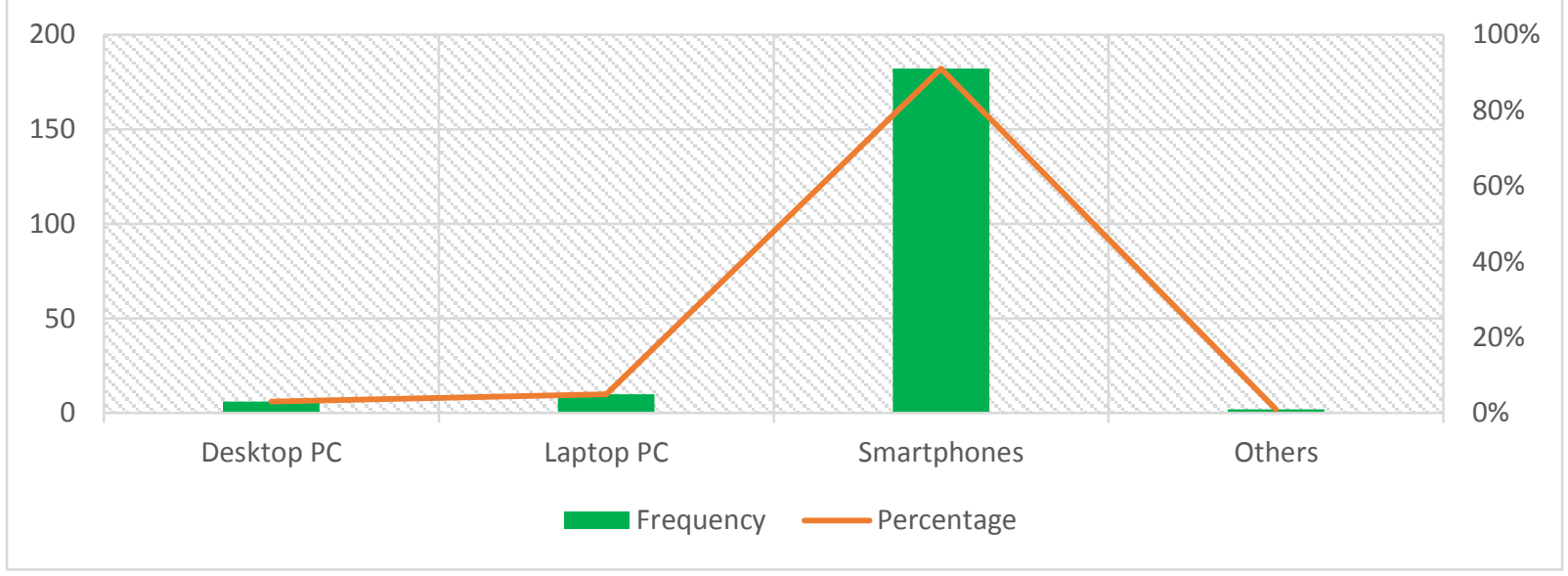

Sources:Primary Data

Mobile technology is becoming prevalent in today's society. Yet despite the widespread use of Internet-accessible mobile

\section{PROBLEMS IN ONLINE CLASS}

Comparing traditional education with online education brings forth significant deficiencies in the online mode such as lack of human connect, absence of opportunities of collaborative learning, teacher supervision and the most glaring being lack of opportunities for hands-on learning in complex subjects such as science and mathematics. Along with that students also face physical health barriers, technical stability, availability online learning site etc.

Table: 5 Problems in Online Class

\begin{tabular}{|l|c|c|l|c|c|}
\hline & Frequency & Percentage & & Frequency & Percentage \\
\hline \multicolumn{3}{|c|}{ Interaction with Co-learners } & \multicolumn{3}{c|}{ Accessibility of Internet } \\
\hline Possible & 82 & $41 \%$ & Easy & 126 & $63 \%$ \\
\hline Impossible & 118 & $59 \%$ & Difficult & 74 & $37 \%$ \\
\hline Total & 200 & $100 \%$ & Total & 200 & $100 \%$ \\
\hline \multicolumn{7}{|c|}{ Up-to-date ICT in Institution } & \multicolumn{3}{c|}{ Security in Online Class } \\
\hline Available & 132 & $66 \%$ & Secure & 76 & $38 \%$ \\
\hline Not Available & 68 & $34 \%$ & Not Secure & 124 & $62 \%$ \\
\hline Total & 200 & $100 \%$ & Total & 200 & $100 \%$ \\
\hline Physical Health Barrers & & Understandability of Online Learning \\
\hline Yes & 120 & $60 \%$ & Understandable & 60 & $30 \%$ \\
\hline
\end{tabular}




\title{
EPRA International Journal of Research and Development (IJRD)
}

\author{
Volume: 6 | Issue: 5 | May 2021
}

- Peer Reviewed Journal

\begin{tabular}{|l|c|c|l|c|c|}
\hline No & 80 & $40 \%$ & Not Understandable & 140 & $70 \%$ \\
\hline Total & 200 & $100 \%$ & Total & 200 & $100 \%$ \\
\hline \multicolumn{2}{|c|}{ Technical Stability in Online Learning } & \multicolumn{2}{c|}{ Availability of Online Learning Site } \\
\hline Yes & 108 & $54 \%$ & Regular & 130 & $65 \%$ \\
\hline No & 92 & $46 \%$ & Irregular & 70 & $35 \%$ \\
\hline Total & 200 & $100 \%$ & Total & 200 & $100 \%$ \\
\hline \multicolumn{2}{|l|}{ Sources:Primary Data }
\end{tabular}

Table 5 shows that problems involved in the online class. Here only $59 \%$ students are able to interact with their co-learners, remaining $41 \%$ students are not able to interact with their co-learners. For $63 \%$ students it is easy to access the internet, the study depicts that $66 \%$ institutions have up-to-date ICT in their institution 34\% institutions re suffer to provide up-to-date technology to their students. When we come to the security in online class it is most danger thing because majority $62 \%$ students were felt that online class is not secure that much. $60 \%$ students are facing health barriers in online class like eye strains, headache, etc. The most important thing found in the study is majority $70 \%$ students are not able to understand the class. Here we can observe that technical stability is also not that much at the same time online sites are also not available every time.

\section{CONCLUSION}

For decades, scholars have debated on which mode of education is superior? Some scholars argue that online is superior and others argue that online is less effective than traditional face-to-face courses. A few others suggest that the hybrid mode (e.g., online blended with face-to-face lectures) is the most desired, inevitable and productive content delivery method for students. However, students' perceptions towards online learning as compared to traditional face-to-face learning have largely been overlooked. As per this study, It is found that majority of the students are facing communication problems, along with that, they are facing internet issues, etc. Thus, they strongly feel that the study environment in traditional class is more conducive for the study because in online class they just attend the class but not able to understand clearly.

\section{REFERENCE}

1. Allen, I.E., \& Seaman, J., (2011). Going the Distance: Online Education in the United States, 2011. Babson Survey Research Group pp. 4-5.

2. Banas, E., \& Emory, W. (1998). History and issues of distance learning, Public Administration Quarterly, 22(3), 365-383.

3. Bernard, R. M., Abrami, P. C., Lou, Y., Borokhovski, E., Wade, A., Wozney, L., \& Huang B. (2004). How does distance education compare with classroom instruction? A meta-analysis of the empirical literature. Review of educational research, 74(3), 379-439.

http://dx.doi.org/10.3102/00346543074003379

4. Brown, J. C., \& Park, H. S. (2016). Longitudinal student research competency: Comparing online and traditional face-to-face learning platforms. Advances in Social Work, 17(1), 44-58. http://dx.doi.org/10.18060/20870

5. Bhuasiri, W., Xaymoungkhoun, O., Zo, H., Rho, J. J., \& Ciganek, A. P. (2012). Critical success factors for e-learning in developing countries: A comparative analysis between ICT experts and faculty. Computers \& Education, 58(2), 843-855. http://dx.doi.org/10.1016/j.compedu. 2011.10.010

6. Cao, Y. (2011). Online versus traditional MBA: An empirical study of students' characteristics, course satisfaction, and overall success, The Journal of Human Resources and Adult Learning, 7(2), 1-12.

7. Cavanaugh, J., \& Jacquemin, S. J. (2015). A large sample comparison of grade-based student learning outcomes in online vs. face-to-face courses. Online Learning Journal, 19(2).

8. Clark, R. A., \& Jones, D. (2001). A comparison of traditional and online formats in a public speaking course. Communication Education, 50(2), 109-124. http://dx.doi.org/10.1080/03634520109379238

9. Cowden, P., \& Sze, S. (2012, July). Online Learning: The Concept of Less Is More. In Allied Academies International Conference. Academy of Information and Management Sciences. Proceedings, 16(2), 1. Jordan Whitney Enterprises, Inc.

10. Deming, D. J., Goldin, C., \& Katz, L. F. (2012). The for-profit postsecondary school sector: Nimble critters or agile predators? Journal of Economic Perspectives, 26(1), 139-164. http://dx.doi.org/10.1257/jep.26.1.139

11. Fedynich, L., Bradley, K. S., \& Bradley, J. (2015). Graduate students' perceptions of online learning. Research in Higher Education Journal, 27, 1.

12. Ferriman, J. (2013). The History of Distance Learning (Infographic). Learn Dash, www.learndash.com/the-history-of-sistance-learning. Retrieved on July 11, 2014.

13. Giroux, H. (2015). Higher education and the promise of democracy. In Future of Higher Education: Perspectives from America's Academic Leaders, 53.

14. Harasim, L. M. (1989). Online education: A new domain. In Mason, R.D. and Kaye, A.R. (editors), 
Mindweave Communication, Computers, and Distance Education, Oxford, Pergamon, Press.

15. Hatcher, M., Henson, J., \& LaRosa, P. (2013). Determinants of success in an online management information systems course: The significance of grade point average as a performance indicator. International Journal of Business Strategy, 13(4), 129-132. http://dx.doi.org/10.18374/IJBS-13-4.7

16. Mayerova,Sarka Hoskova-Zdena Rosicka ( 2015) ELearning Pros And Cons: Active Learning Culture? Procedia - Social and Behavioural Sciences 191 (2015) 958 - 962, Available online at www.sciencedirect.com. WCES 2014, 1877-0428, 2015 Published by Elsevier Ltd.

17. Miller, G. (2014). History of Distance Learning. Retrieved May 5, 2016 at: http://www.worldwidelearn.com/educationarticles/history-of-distance-learning.html

18. Moore, M. (1990). Recent contributions to the theory of distance education. Open leaning, 5(3), 1015. http://dx.doi.org/10.1080/0268051900050303

19. Murdock, J., William, A., Becker, K., Bruce, M., \& Young, S. (2012). Online versus on-campus: A comparison study of skills sources, The Journal of Human Resources and Adult Learning, 8(1), 105-118.

20. Neuhauser, C. (2010). Learning style and effectiveness of online and face-to-face instruction. The American Journal of Distance Education.

21. Sangrà A, Vlachopoulos D and Cabrera, N. Building an Inclusive Definition of E- Learning: An Approach to the Conceptual Framework. The International Review on Research in Open and Distance Learning, 13 (2), 2012

22. Schlosser, L.A., \& Simonson, M.R. (2009). Distance education: Definitions and glossary of terms. IAP, 2009.

23. Shotwell, M., \& Apigian, C. H. (2015). Student performance and success factors in learning business statistics in online vs. on-ground classes using a webbased assessment platform. Journal of Statistics Education, 23(1), 1-19. 